\title{
ADEQUACY OF DRAINAGE CHANNELS IN A SMALL URBAN WATERSHED IN NIGERIA
}

\author{
C.S Adaba ${ }^{1}$ and J.C. Agunwamba ${ }^{2}$

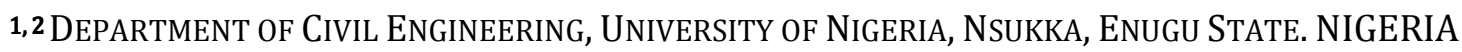 \\ E-mail addresses:1 realsandra@rocketmail.com,2 nwambaagu@yahoo.com
}

\begin{abstract}
This research presents an analysis for the adequacy of drainage channels. Topographical and location map was used as a guide to locate the drainage channels. Rainfall records for a period of four years (2008-2011) were used to develop the intensity-duration frequency of the study area. Field survey and geometrical measurement of the drainage channels were carried out and data obtained from the measurement were used for the analysis of runoff from drainage channels. The time of concentration was determined using the Kirpich equation and modified version of Kirpich equation (new equation of time of concentration). The peak flow and maximum flow velocity from the drainage channels were determined using the rational model and manning's equation. Analysis of the results showed that most of the drainage channels had lesser runoff when the modified Kirpich equation was used. All the drainage channels of basin $A$ had velocities ranging from $1 \mathrm{to} 2 \mathrm{~m} / \mathrm{s}$ and the drain capacities are okay. All the drainage channels of basin $B$ had velocities ranging from 2 to $4 \mathrm{~m} / \mathrm{s}$ and the drain capacities are okay. Channels 2 and 9 of basin $C$ had drain capacity less than the actual discharge this makes the drain inadequate. Basin $C$ revealed that, channels 1, 4, 5, 7, 8, 10, 12 and 13 have flow velocities less than $1 \mathrm{~m} / \mathrm{s}$ and this will cause deposition of sediment, a redesign of inadequate drainage channels with velocity less than $1 \mathrm{~m} / \mathrm{s}$ was done and their velocities ranges from $1.21 \mathrm{~m} / \mathrm{s}$ to $1.54 \mathrm{~m} / \mathrm{s}$. A redesign of drainage channels 2 and 9 of basin $C$ showed that the drain capacity were greater than the actual discharge and this makes the drain adequate.This study suggests that; proper design, analysis, construction and maintenance of drainage channels be made.
\end{abstract}

Keywords: Time of concentration, drainage capacity, velocity and discharge.

\section{INTRODUCTION}

The area upon which waterfalls and the network through which it travels to an outlet is referred to as a drainage system. Storm water management systems are designed to control the quantity, quality, timing and distribution of runoff resulting from storm events [1]. Adequate drainage is essential in the design of highways since it affects the highways serviceability and usable life.

The drainage designs involves providing facilities that collect, transport and remove the water from the highway. Hydrologists have been studying the flow or runoff of water overland for many decades, and some rather sophisticated theories have been proposed to describe the process unfortunately most of these attempts have been only partially successful, not only because of the complexity of the process and the many interactive factors involved, but also because of the stochastic nature of rainfall and other source of water. Runoff from an urban drainage catchment consists of an initial runoff from impervious area (such as roofs, buildings, roads and parking lots), which flows into the storm drainage system.

In the design of a drainage system, estimation of the quantity of runoff and the dimensions of the drains are very important. The appropriate method of determination of runoff depends on its applicability to the area concern, the quantity and type of data available, the detail and accuracy required and the importance of the structure [2]. Usually, the rational method is applied particularly for small urban watershed or catchment. The rational method states

* The corresponding author Sandra C. Adaba died a few weeks after submitting the final revised copy of this article during child delivery at Umuahia, Abia State, NIGERIA. Until her painful demise, Mrs. Adaba was a doctoral student under the supervision of Prof. J. C. Agunwamba of Civil Engineering Department, University of Nigeria Nsukka, NIGERIA. She was expected to graduate by August 2015. 
that; runoff discharge (Q) depends greatly on the rainfall intensity (i), coefficient of $\operatorname{runoff}(\mathrm{C})$ and the catchment area. The rainfall intensity is often read from an intensity-duration curve. This is possible if both the duration $\left(\mathrm{T}_{\mathrm{c}}\right)$ and the storm return period $(\mathrm{T})$ are known.

The assessment of extreme precipitation is an important problem in hydrologic risk analysis and design. This is why the evaluation of rainfall extremes, as embodied in the intensity-duration frequency (IDF) relationship, has been a major focus of both theoretical and applied hydrology [3]. According to Brian [4], rainfall frequency analyses are used extensively in the design of systems to handle storm runoff, including roads, culverts and drainage systems. IDF estimates are important statistical summaries of precipitation records used for hydrologic engineering design [5].

The time of concentration is the time it would take for a drop of rainwater in a reasonable intense storm to get from the farthest point on the catchment to the bottom of the catchment

Kirpich [6], proposed an empirical equation to determine the time of concentration for channel flow given as:

$\mathrm{T}_{\mathrm{c}}=0.019 \mathrm{~L}^{0.77} / \mathrm{S}^{0.385}$

A new time of concentration was also proposed in this study for channel flow given as:

$\mathrm{T}_{\mathrm{c}}=0.076 \mathrm{~L}^{0.354} / \mathrm{S}^{0.71}$

Where $\mathrm{L}$ is the flow path distance from the remotest part of the water catchment to the drain outlet (m) and $\mathrm{S}$ is the slope. These parameters are determined from the topographical map of the study area. The modified Kirpich equation (new equation of time of concentration) was established so as to make comparison and ascertain if there will be a reduction in discharge from the drainage channels when used in the analysis since both equations only considered the channel flow component of runoff.

It is considered good practice to use at least three different methods to estimate the time of concentration and, within the range of these estimates, the final value should be selected by judgment [7].

Drainage system can fail if not properly designed hence, detailed design information of the drain is important to ensure easy and effective maintenance of the drainage. It is important to note that drainage systems are designed to a set of criteria that are subject to economic, social and environmental constraints. The design process should be one of risk management where by the consequences of larger events order than the design event are assessed for their cost and environmental impacts. In practices, drainage design for an area will involve a network of drains of different sizes to be laid at various slopes. Different methods may be employed in the design of drains. The methods range from trial and error selection of the sizes and checking whether or not the velocity of flow and capacity are satisfied. The drains are designed with discharge determined using the rational formula. The chosen section must give a capacity, $Q_{c}$ greater than the value designed for [2]. It is a good practice to always design channels for the best hydraulic section with modification on practicability of its construction. Hydraulically, the section having the least wetted perimeter for a given area has the maximum discharging capacity. Such a section is called the best hydraulic section [8].

ASCE [9] recommended that, all channels carrying supercritical flow should be lined with concrete and continuously reinforced both longitudinally and laterally and manning's roughness coefficient less than 0.013 should not be used for well- troweled concrete for open channel design. The objectives of this paper are; to determine the adequacy of existing drainage channels, where necessary redesign inadequate drainage channels and develop a rainfall intensity duration frequency relationship used for the analysis.

\section{STUDY AREA}

The study area is the University of Nigeria Nsukka located on the North-East of commercial area of Nsukka town and due east of hill in Enugu state Nigeria. Water flows from the catchment into a lower land a small settlement called Alaono. UNN has an altitude of about $500 \mathrm{~m}$ with temperature ranging from 20 to $33^{\circ} \mathrm{C}$. The entire area is about $7,329,9925 \mathrm{~m}^{2}$. There are two seasons in the area, the wet season (March through November) and dry season (December through February). During the rainy season, a marked interruption in the rains occurs during August, resulting in a short dry season referred to as the "August break", though for years now this has not been consistent in August due to the climate change. UNN has annual rainfall of about $1600 \mathrm{~mm}$ with greatest intensity of about $144 \mathrm{~mm} / \mathrm{hr}$. Large part of the catchment consists of hilly terrain covered by vegetation, the lower parts of the catchment consists of buildings and roads. The valley floor slopes gently to the West and North West at 
approximately $3 \%$. The site lies within the basal sand stone of the upper coal measures which consists of fine grained false bedded sand stones and flat stones of about $15 \mathrm{~m}$ thick; lying on $10 \mathrm{~m}$ of clayey sandstones. The soil is reddish brown in colour; belong to the soil group of medium plastic and medium graded sand of low fertility. The bearing pressure of the soil varies between 100 to $250 \mathrm{KN} / \mathrm{m}^{2}$. The soft sands are prone to erosion with rapid permeability.

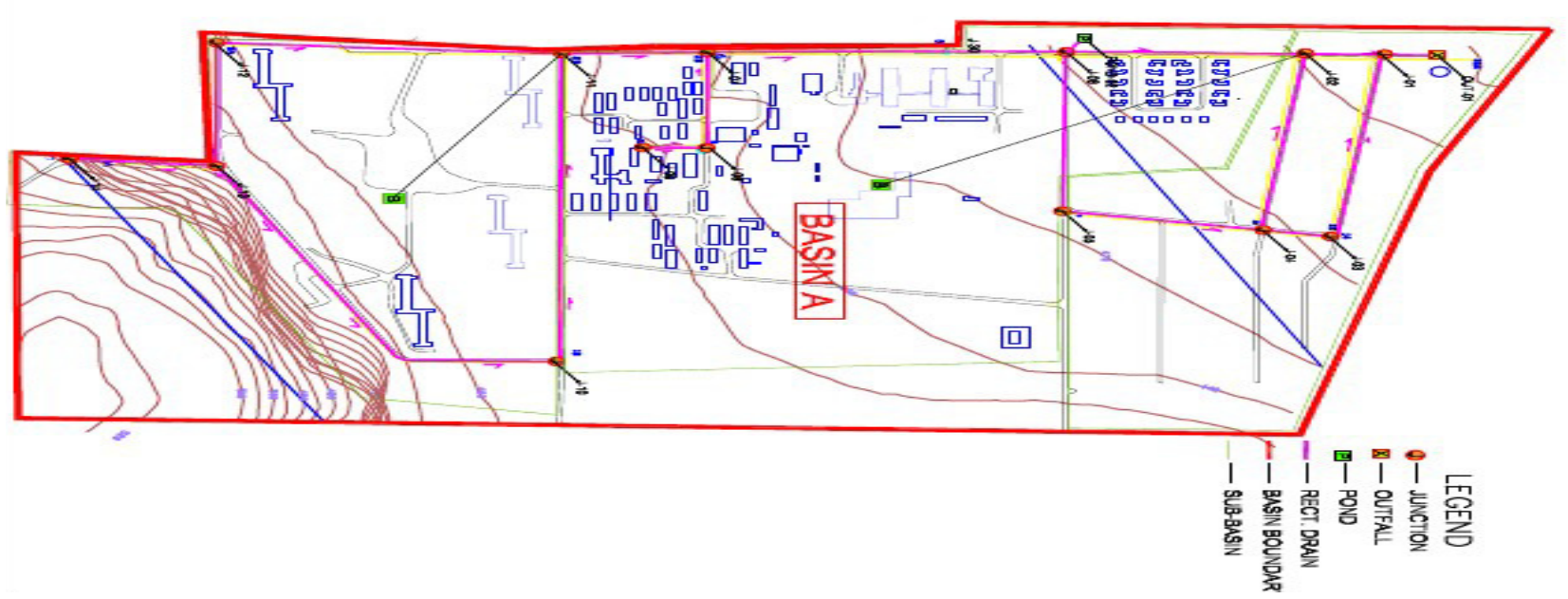

Figure 1.0: Map of basin A showing the network of drains and outfalls

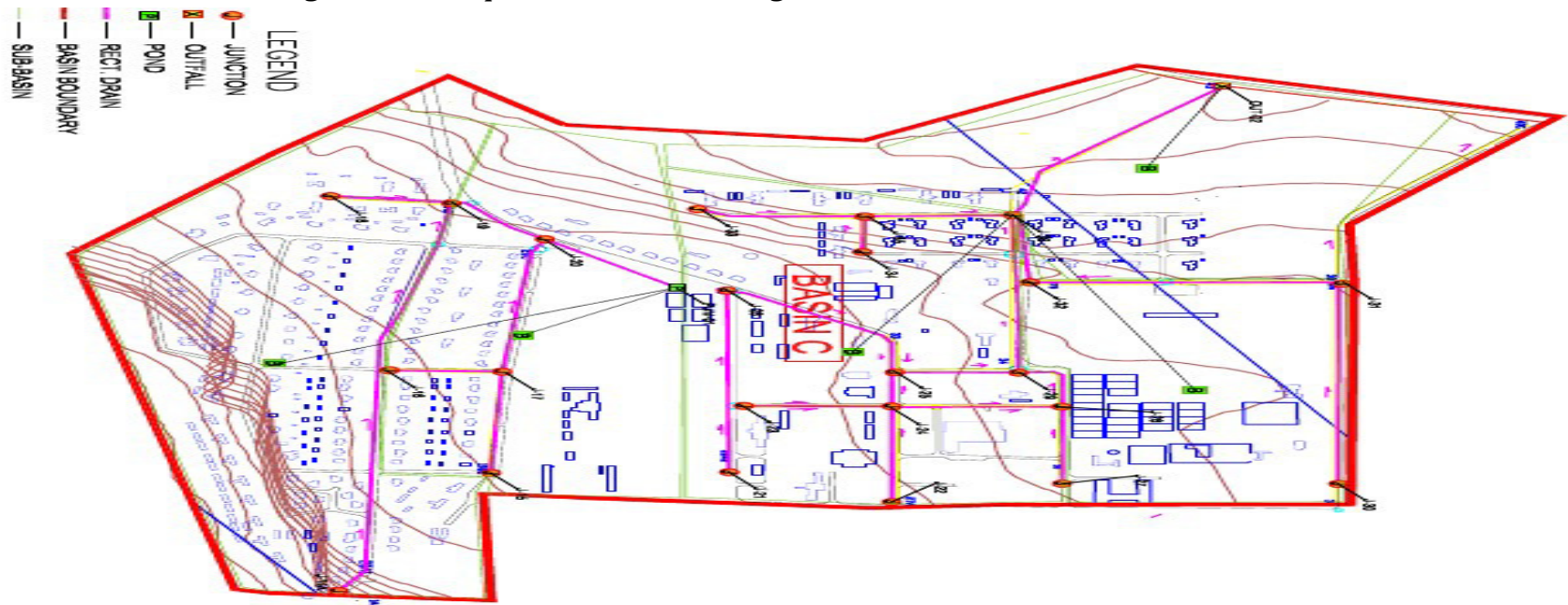

Figure 2: Map of basin C showing the network of drains and outfalls

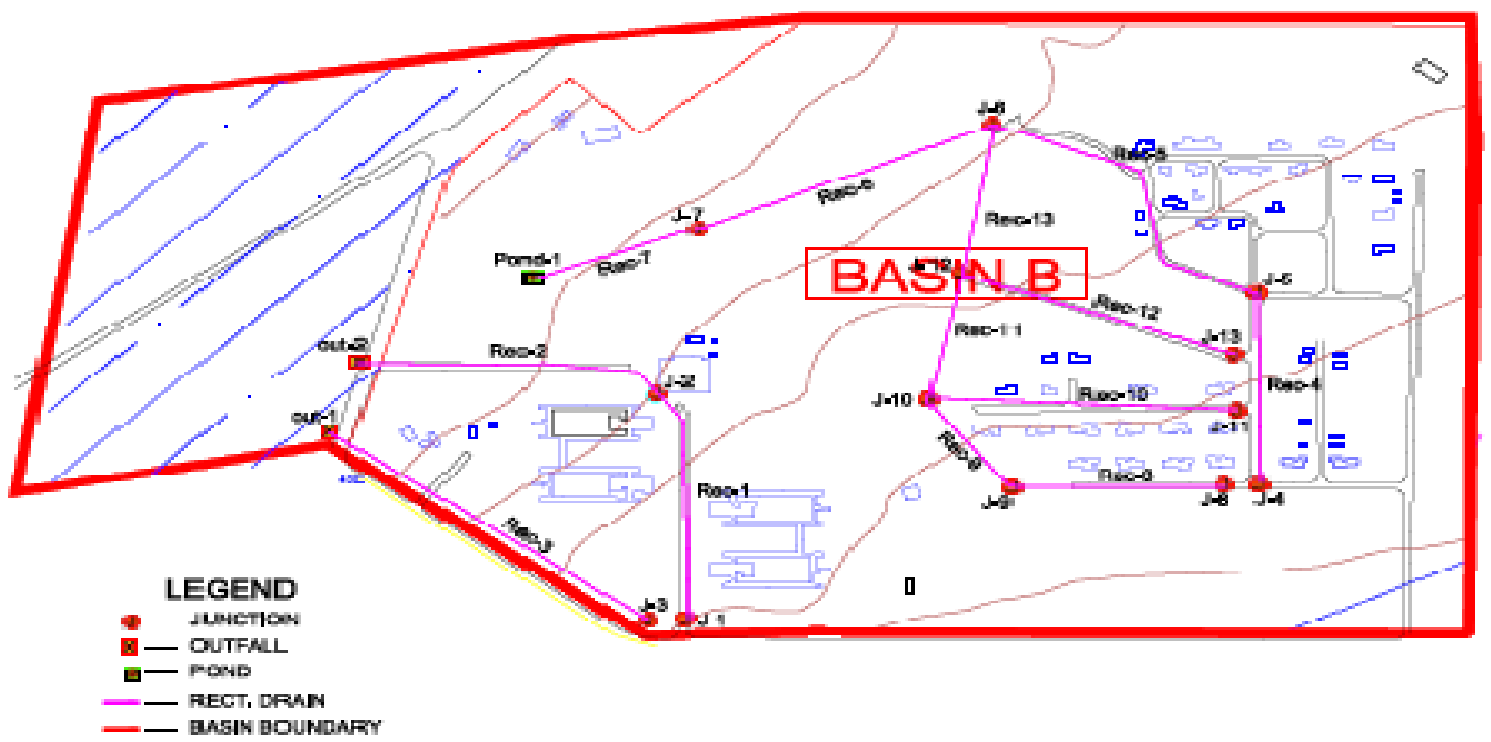

Figure 3: Map of basin B showing the network of drains and outfall 


\section{MATERIALS AND METHODS}

The materials used were topographical map, location map, current meter, stopwatch, book and pen, $10 \mathrm{~m}$ and $50 \mathrm{~m}$ tape, iron pegs, harmer, white paint, rainfall data for a period of 4 years at 5 minutes interval using automated rain gauges (Secondary Source obtained from Centre for Basic Space Science UNN) and a Gis based software.

The network of drainage channels and their locations were identified using the topographical map. Thereafter, the geometric measurement (width and depth) of the existing drainage channels were measured with a tape. The length and slope parameters are determined from the topographical map and this was imported on a Gis based software (Stormnet modeling software) which shows the drainage network and their outfalls as shown in figures 1, 2 and 3 respectively.

Observed time of concentration for channel flow was obtained through field measurement by estimating the distance from the top of the catchment to the bottom, by estimating the velocity of flow from drainage channels and by calculating the time it takes to travel that distance. The selected subcatchment was divided into nine sub areas; this was done such that the time of concentration increases from one sub-area to another. The time of concentration for sub area A, B, C, D, E, F,G,H and I are 2, 4, 6,8,10,12,14,16 and 18 minutes respectively. The channel lengths are $128 \mathrm{~m}$, $168 \mathrm{~m}, 186 \mathrm{~m}, 376 \mathrm{~m}, 440 \mathrm{~m}, 800 \mathrm{~m}, 1082 \mathrm{~m}, 1714 \mathrm{~m}$ and $1956 \mathrm{~m}$ with a corresponding slope of $0.055,0.054$, $0.043,0.032,0.029,0.024,0.023,0.022$ and 0.014 respectively. The corresponding flow velocities from the channels are $1.07 \mathrm{~m} / \mathrm{s}, 0.70 \mathrm{~m} / \mathrm{s}, 0.52 \mathrm{~m} / \mathrm{s}, 0.78 \mathrm{~m} / \mathrm{s}$, $0.73 \mathrm{~m} / \mathrm{s} 1.11 \mathrm{~m} / \mathrm{s} 1.29 \mathrm{~m} / \mathrm{s}, 1.78 \mathrm{~m} / \mathrm{s}$ and $1.811 \mathrm{~m} / \mathrm{s}$ respectively.

The empirical model was developed using the multiple method of Regression to work on results obtained from field. In order to make the computation analysis less rigorous, the Microsoft excel package was used. The time of concentration equation is of this form: $\mathrm{T}_{\mathrm{c}}=\mathrm{a} \mathrm{L}^{\mathrm{b}} \mathrm{S}^{\mathrm{c}} 3.0$
Linearizing we obtain

$\operatorname{lnt}_{\mathrm{c}}=\ln \mathrm{a}+\mathrm{blnL}+\mathrm{clnS}$

The parameters $\mathrm{t}, \mathrm{S}$ and $\mathrm{L}$ are obtained from field measurement and observation.

Where, $t_{c}$ is the time of concentration in minutes, $L$ is the length of channel in meters and $S$ is the slope. $a, b$ and $\mathrm{c}$ are constant obtained using the multiple regression model.

Applications of Microsoft excel to solve the matrix the constants are obtained as follows: $\mathrm{a}_{0}=-1.1166$, $\mathrm{b}=0.354$ and $\mathrm{c}=-0.71$.

Taking the antilog to base 10 to convert the linearized time of concentration equation back to the original form (non linear form) demands that, $\mathrm{a}=10^{\mathrm{a}} 0$; this implied that $\mathrm{a}=10^{-1.1166}=0.076$

$\mathrm{T}_{\mathrm{c}}=0.076 \mathrm{~L}^{0.354} / \mathrm{S}^{0.71}$

The empirical model result of time of concentration was compared with the observed time of concentration from field and Kirpich equation of time of concentration of channel flow.

For a rainfall record containing several years of data, the following computations lead to the IDF curve:

1) For a given duration of time, starting with $\Delta t$, the maximum rainfall amount of each duration in each year were determined

2) The precipitation amounts, one for each year were ranked in order of magnitude and the return period $\mathrm{T}$, for each precipitation amount were estimated using the Weibull formular

$\mathrm{T}=\mathrm{n}+1 / \mathrm{m}$

Where $n$ is the number of years of data and $m$ is the rank of the data corresponding to the event with return period.

3) Steps 1 and 2 were repeated with the duration increased duration by $\Delta t$. A maximum duration of 30 mins was used in this study.

4) For each return period, the precipitation amount were divided by the duration in order to obtain the average intensity, this was plotted against the duration for each return period using Microsoft excel to yield the IDF curve.

Table 1: Frequency of Occurrence (T) for Year 2008-2011 using Selected Maximum Accumulated Rainfall(mm) at Duration of 5-30 Minutes

\begin{tabular}{ccccccccc}
\hline Yrs/Duration & 5 & 10 & 15 & 20 & 25 & 30 & ranking & freq=n/m +1 \\
\hline 2009 & 9.6 & 17.5 & 24.3 & 29.1 & 36.1 & 40.9 & 1 & 5.00 \\
2011 & 9.3 & 16.9 & 21.3 & 27.2 & 30.4 & 32.1 & 2 & 3.00 \\
2008 & 8.8 & 17.0 & 22.0 & 26.7 & 29.8 & 32.0 & 3 & 2.33 \\
2010 & 7.9 & 14.7 & 19.3 & 24.4 & 27.6 & 30.1 & 4 & 2.00 \\
\hline
\end{tabular}


Table 2: Average Rainfall Intensity $(\mathrm{mm} / \mathrm{hr})$ for Storm of 5 yrs Frequency

\begin{tabular}{cccc}
\hline $\begin{array}{c}\text { Duration(m } \\
\text { ins) }\end{array}$ & $\begin{array}{c}\text { duration( } \\
\text { hrs })\end{array}$ & $\begin{array}{c}\text { ppt(m } \\
\mathrm{m})\end{array}$ & $\begin{array}{c}\text { ave.R.inensity(m } \\
\mathrm{m} / \mathrm{hr})\end{array}$ \\
\hline 5 & 0.083 & 9.6 & 115.70 \\
10 & 0.166 & 17.5 & 105.42 \\
15 & 0.25 & 24.3 & 97.20 \\
20 & 0.333 & 29.1 & 87.30 \\
25 & 0.416 & 36.1 & 86.57 \\
30 & 0.5 & 40.9 & 81.80 \\
\hline
\end{tabular}

Table 3: Average Rainfall Intensity ( $\mathrm{mm} / \mathrm{hr}$ ) for Storm of 3 yrs Frequency

\begin{tabular}{cccc}
\hline $\begin{array}{c}\text { Duration(mi } \\
\text { ns) }\end{array}$ & $\begin{array}{c}\text { Duration(h } \\
\text { rs) }\end{array}$ & $\begin{array}{c}\mathrm{ppt}(\mathrm{m} \\
\mathrm{m})\end{array}$ & $\begin{array}{c}\text { Ave.R.inensity(m } \\
\mathrm{m} / \mathrm{hr})\end{array}$ \\
\hline 5 & 0.083 & 9.3 & 112.05 \\
10 & 0.166 & 16.9 & 101.80 \\
15 & 0.25 & 21.3 & 85.20 \\
20 & 0.333 & 27.2 & 81.70 \\
25 & 0.416 & 30.4 & 72.00 \\
30 & 0.5 & 32.1 & 64.20 \\
\hline
\end{tabular}

Table 4: Average Rainfall Intensity ( $\mathrm{mm} / \mathrm{hr}$ ) for Storm of 2.3 yrs Frequency

\begin{tabular}{cccc}
\hline $\begin{array}{c}\text { Duration(mi } \\
\text { ns) }\end{array}$ & $\begin{array}{c}\text { Duration(h } \\
\text { rs) }\end{array}$ & $\begin{array}{c}\text { Ppt(m } \\
\text { m) }\end{array}$ & $\begin{array}{c}\text { Ave.R.inensity(m } \\
\text { m/hr) }\end{array}$ \\
\hline 5 & 0.083 & 8.80 & 106.02 \\
10 & 0.166 & 17.00 & 102.41 \\
15 & 0.25 & 22.00 & 88.00 \\
20 & 0.333 & 26.70 & 80.18 \\
25 & 0.416 & 29.80 & 71.52 \\
30 & 0.5 & 32.00 & 64.00 \\
\hline
\end{tabular}

Table 5: Average Rainfall Intensity ( $\mathrm{mm} / \mathrm{hr}$ ) for Storm of 2 yrs Frequency

\begin{tabular}{cccc}
\hline $\begin{array}{c}\text { Duration(mi } \\
\text { ns) }\end{array}$ & $\begin{array}{c}\text { Duration(h } \\
\text { rs) }\end{array}$ & $\begin{array}{c}\operatorname{ppt}(\mathrm{m} \\
\mathrm{m})\end{array}$ & $\begin{array}{c}\text { Ave.R.inensity(m } \\
\mathrm{m} / \mathrm{hr})\end{array}$ \\
\hline 5 & 0.083 & 7.9 & 95.18 \\
10 & 0.166 & 14.7 & 88.55 \\
15 & 0.25 & 19.3 & 77.20 \\
20 & 0.333 & 24.4 & 73.27 \\
25 & 0.416 & 27.6 & 66.24 \\
30 & 0.5 & 30.1 & 60.20 \\
\hline
\end{tabular}

The Kirpich's equation for time of concentration and the modified Kirpich equation (new time of concentration equation) were used to compute $\left(\mathrm{T}_{\mathrm{c}}\right)$ With the time of concentration determined, the IDF curve developed was used to obtain the rainfall intensity using a return period of 2 yrs specified for drainage design.

The rational model and manning's equation were used to generate the peak flow runoff, maximum velocity and design discharge capacity of the drainage channels given as:

$\mathrm{Q}=\mathrm{CIA}$
Where, $Q$ is the peak runoff $\left(\mathrm{m}^{3} / \mathrm{s}\right), C$ is the runoff coefficient, I is the rainfall intensity $(\mathrm{mm} / \mathrm{hr})$ and $A$ is the area of the drainage basin $\left(\mathrm{m}^{2}\right)$.

\section{RESULTS AND DISCUSSION}

A new time of concentration equation was used for the analysis of the drainage channels and this was compared with the results obtained from Kirpich equation of time of concentration.

Results obtained from the analysis of drainage channels of basins A, B and C showed that a relationship exist between the rainfall intensity and the time ofconcentration. As the time of concentration reduces, the rainfall intensity increases. At time of concentration of $5 \mathrm{mins}$, an intensity of rainfall of $95 \mathrm{~mm} / \mathrm{hr}$ was observed while a time of concentration of $12 \mathrm{mins}$ had rainfall intensity of $85 \mathrm{~mm} / \mathrm{hr}$ as shown in Figure 5

Comparison of the equations of time of concentration, revealed a slight difference in runoff discharge ranging from $0.002 \mathrm{~m}^{3} / \mathrm{s}$ to $0.005 \mathrm{~m}^{3} / \mathrm{s}$ in basin $\mathrm{A}$ as shown in Tables 6 and Figure 6. However, a reduction in runoff discharge was observed in basin $\mathrm{C}$ when the new time of concentration equation was used for the analysis as shown in Tables 8 and Figure 7 respectively. The results obtained from the analysis of the new equation of time of concentration appears better than analysis from Kirpich's equation of time of concentration since there was a reduction in runoff discharge.

Drainage channels 2 of basin A, had a quantity of runoff of $0.464 \mathrm{~m}^{3} / \mathrm{s}$ when the Kirpich equation was used while, a runoff discharge of $0.489 \mathrm{~m}^{3} / \mathrm{s}$ was observed in the analysis from the new time of concentration equation at a velocity of $2.04 \mathrm{~m} / \mathrm{s}$ with a slope of $9.25 \%$ and drain capacity of $1.647 \mathrm{~m}^{3} / \mathrm{s}$ as shown in tables 6 and figure 6 respectively. Channels 5 had the least discharge of $0.063 \mathrm{~m}^{3} / \mathrm{s}$ with a velocity of $1.63 \mathrm{~m} / \mathrm{s}$ at $6.66 \%$ slope and drain capacity of $0.636 \mathrm{~m}^{3} / \mathrm{s}$. All the drainage channels of basin A had velocities ranging from 1 to $2 \mathrm{~m} / \mathrm{s}$, the flow velocity meets the requirement of $1-3 \mathrm{~m} / \mathrm{s}$ and the drain capacities are okay as shown in tables 6 and figure 6 respectively .

All the drainage channels of basin B had velocities ranging from 2 to $4 \mathrm{~m} / \mathrm{s}$ and the drain capacities are okay as shown in Tables 7 and Figure 7 respectively. Channels 9 of basin $\mathrm{C}$ had the highest discharge of $1.524 \mathrm{~m}^{3} / \mathrm{s}$ with a flow velocity of $1.91 \mathrm{~m} / \mathrm{s}$ and a drain capacity of $0.688 \mathrm{~m}^{3} / \mathrm{s}$. The drainage capacity is less 
than the actual discharge this makes the drain inadequate as shown in tables 8and figure 8 respectively.

Tables 8 of basin $C$ revealed that, channels $1,4,5,7,8$, 10, 12 and 13 have flow velocities less than $1 \mathrm{~m} / \mathrm{s}$. A flow velocity less than minimum requirement of $1 \mathrm{~m} / \mathrm{s}$ will cause deposition of sediments in the drain. Field observation of these drains showed that the drains had been silted by sediments. A redesign of inadequate drainage channels of basin c was done and the result showed that, their velocities ranges from $1.21 \mathrm{~m} / \mathrm{s}$ to $1.54 \mathrm{~m} / \mathrm{s}$ as shown in Tables 9.0. However, velocities excess of $6 \mathrm{~m} / \mathrm{s}$ should be avoided to prevent scouring on the drains. Drainage Channels 2 and 9 of basin C had drain capacity of $0.821 \mathrm{~m}^{3} / \mathrm{s}$ and $2.06 \mathrm{~m}^{3} / \mathrm{s}$ respectively with corresponding drain size of $0.4 \mathrm{mx} 0.8 \mathrm{~m}$ and $0.45 \mathrm{mx} 0.90 \mathrm{~m}$ respectively as shown in tables 9.0. Since the drain capacity exceeds the actual discharge, the drainage channels are adequate.

Table 6: Analysis to Determine Adequacy and Capacity of Drainage Channels for Basin A

\begin{tabular}{|c|c|c|c|c|c|}
\hline $\mathrm{CH}$ & 1 & 2 & 3 & 4 & 5 \\
\hline Catchment $\mathrm{A}\left(\mathrm{m}^{2}\right)$ & 10000 & 28261 & 3877 & 7378 & 3902 \\
\hline Ave runoff coe & 0.65 & 0.65 & 0.65 & 0.65 & 0.65 \\
\hline Return period & $2 y r s$ & $2 y r s$ & $2 y r s$ & $2 y r s$ & $2 y r s$ \\
\hline $\mathrm{T}_{\mathrm{c}} \mathrm{K}$ (mins) & 13 & 7 & 6 & 5 & 8 \\
\hline $\mathrm{TcN}$ (mins) & 14 & 4 & 5 & 3 & 5 \\
\hline $\mathrm{I}_{\mathrm{K}}(\mathrm{mm} / \mathrm{hr})$ & 82 & 91 & 93 & 95 & 90 \\
\hline $\mathrm{I}_{\mathrm{N}}(\mathrm{mm} / \mathrm{hr})$ & 79 & 96 & 95 & 97 & 95 \\
\hline Manning's coe(n & 0.013 & 0.013 & 0.013 & 0.013 & 0.013 \\
\hline Drain size $(b \times y)$ & $0.6 \times 0.6$ & $0.95 \times 0.85$ & $0.25 \times 0.3$ & $0.25 \times 0.3$ & $0.6 \times 0.65$ \\
\hline Drain type & Rectangular & Rectangular & Rectangular & Rectangular & Rectangular \\
\hline Slope \% & 1.633 & 9.250 & 5.113 & 9.635 & 6.663 \\
\hline $\operatorname{Velocity}(\mathrm{m} / \mathrm{s})$ & 1.49 & 2.04 & 1.88 & 1.68 & 1.63 \\
\hline $\mathrm{Q}_{\mathrm{K}}\left(\mathrm{m}^{3} / \mathrm{s}\right.$ & 0.148 & 0.464 & 0.065 & 0.126 & 0.063 \\
\hline $\mathrm{QN}\left(\mathrm{m}^{3} / \mathrm{s}\right.$ & 0.143 & 0.489 & 0.063 & 0.129 & 0.067 \\
\hline $\mathrm{Q}_{\mathrm{c}}\left(\mathrm{m}^{3} / \mathrm{s}\right)$ & 0.536 & 1.647 & 0.141 & 0.130 & 0.636 \\
\hline Ch length (m) & 619 & 661 & 398 & 398 & 525 \\
\hline Inlet invert ele(m) & 460.50 & 421.25 & 380.50 & 378.50 & 412.40 \\
\hline Inlet invert offset & 1.10 & 1.10 & 1.10 & 1.10 & 1.10 \\
\hline Outlet invert ele(m) & 450.40 & 360.15 & 360.15 & 340.15 & 377.40 \\
\hline Outlet invert offset & 1.10 & 1.10 & 1.10 & 1.10 & 1.10 \\
\hline Remark & Drain capacity ok & $\begin{array}{c}\text { Drain capacity } \\
\text { ok }\end{array}$ & $\begin{array}{c}\text { Drain capacity } \\
\text { ok }\end{array}$ & $\begin{array}{c}\text { Drain capacity } \\
\text { ok }\end{array}$ & $\begin{array}{c}\text { Drain } \\
\text { capacity ok }\end{array}$ \\
\hline
\end{tabular}

Table 7.: Analysis to Determine Adequacy and Capacity of Drainage Channels for Basin B

\begin{tabular}{|c|c|c|c|c|c|}
\hline $\mathrm{CH}$ & 1 & 2 & 3 & 4 & 5 \\
\hline Catchment $\mathrm{A}\left(\mathrm{m}^{2}\right)$ & 42806 & 28192 & 48292 & 77104 & 33220 \\
\hline Ave runoff coe & 0.55 & 0.50 & 0.55 & 0.45 & 0.5 \\
\hline Return period & $2 y r s$ & $2 y r s$ & $2 \mathrm{yrs}$ & $2 y r s$ & $2 y r s$ \\
\hline $\mathrm{T}_{\mathrm{c}} \mathrm{K}$ (mins) & 24 & 16 & 9 & 13 & 9 \\
\hline $\mathrm{TcN}$ (mins) & 22 & 12 & 9 & 11 & 12 \\
\hline $\mathrm{I}_{\mathrm{K}}(\mathrm{mm} / \mathrm{hr})$ & 67 & 76 & 89 & 82 & 89 \\
\hline $\mathrm{I} \mathrm{N}(\mathrm{mm} / \mathrm{hr})$ & 70 & 85 & 89 & 87 & 85 \\
\hline Manning's coe(n & 0.013 & 0.013 & 0.013 & 0.013 & 0.013 \\
\hline Drain size(b x y) & $0.6 \times 0.6$ & $0.6 \times 0.6$ & $0.6 \times 0.6$ & $0.6 \times 0.6$ & $0.6 \times 0.6$ \\
\hline Drain type & Rectangular & Rectangular & Rectangular & Rectangular & Rectangular \\
\hline Slope \% & 1.12 & 2.50 & 2.90 & 2.40 & 1.60 \\
\hline $\operatorname{Velocity}(\mathrm{m} / \mathrm{s})$ & 2.783 & 4.160 & 4.50 & 4.074 & 3.327 \\
\hline $\mathrm{Q}_{\mathrm{K}}\left(\mathrm{m}^{3} / \mathrm{s}\right.$ & 0.438 & 0.298 & 0.657 & 0.790 & 0.411 \\
\hline $\mathrm{QN}\left(\mathrm{m}^{3} / \mathrm{s}\right.$ & 0.458 & 0.333 & 0.657 & 0.838 & 0.392 \\
\hline $\mathrm{Q}_{\mathrm{c}}\left(\mathrm{m}^{3} / \mathrm{s}\right)$ & 1.000 & 1.497 & 1.612 & 1.467 & 1.198 \\
\hline Ch length (m) & 1108 & 980 & 546 & 754 & 371 \\
\hline Inlet invert ele(m) & 460.50 & 420.25 & 380.50 & 375.50 & 410.40 \\
\hline Inlet invert offset & 1.10 & 1.10 & 1.10 & 1.10 & 1.10 \\
\hline Outlet invert ele(m) & 430.40 & 350.15 & 360.15 & 340.15 & 360.40 \\
\hline Outlet invert offset & 1.10 & 1.10 & 1.10 & 1.10 & 1.10 \\
\hline
\end{tabular}

Remark

Drain capacity ok Drain capacity ok Drain capacity ok Drain capacity ok Drain capacity ok 
Table 8.: Analysis to Determine Adequacy and Capacity of Drainage Channels for Basin C

\begin{tabular}{|c|c|c|c|c|c|c|}
\hline $\mathrm{CH}$ & 1 & 2 & 3 & 4 & 5 & 6 \\
\hline Catchment $\mathrm{A}\left(\mathrm{m}^{2}\right)$ & 17333 & 55079 & 3735 & 11235 & 6116 & 18763 \\
\hline Ave runoff coe & 0.5 & 0.5 & 0.65 & 0.65 & 0.5 & 0.5 \\
\hline Return period & $2 y r s$ & $2 y r s$ & $2 y r s$ & $2 y r s$ & $2 y r s$ & $2 y r s$ \\
\hline $\mathrm{T}_{\mathrm{c}} \mathrm{K}$ (mins) & 8 & 4 & 4 & 5 & 10 & 12 \\
\hline TcN(mins) & 19 & 11 & 5 & 8 & 19 & 23 \\
\hline $\mathrm{I}_{\mathrm{K}}(\mathrm{mm} / \mathrm{hr})$ & 90 & 96 & 96 & 95 & 88 & 85 \\
\hline $\mathrm{I}_{\mathrm{N}}(\mathrm{mm} / \mathrm{hr})$ & 72 & 86 & 95 & 90 & 75 & 69 \\
\hline Manning's coe(n) & 0.013 & 0.013 & $”$ & " & , & , \\
\hline Drain size(b x y) & $0.6 \times 0.6$ & ", & $”$ & ", & " & $"$ \\
\hline Drain type & Rect & $"$ & $”$ & " & " & , \\
\hline Slope \% & 0.547 & 0.95 & 4.31 & 1.73 & 0.71 & 0.578 \\
\hline $\operatorname{Vel}(\mathrm{m} / \mathrm{s})$ & 0.68 & 1.04 & 1.14 & 0.96 & 0.97 & 0.95 \\
\hline $\mathrm{QK}\left(\mathrm{m}^{3} / \mathrm{s}\right)$ & 0.217 & 0.734 & 0.065 & 0.193 & 0.075 & 0.221 \\
\hline $\mathrm{QN}\left(\mathrm{m}^{3} / \mathrm{s}\right)$ & 0.173 & 0.658 & 0.064 & 0.183 & 0.064 & 0.180 \\
\hline $\mathrm{Q}_{c}\left(\mathrm{~m}^{3} / \mathrm{s}\right)$ & 0.245 & 0.374 & 0.41 & 0.346 & 0.349 & 0.342 \\
\hline Ch length (m) & 183 & 105 & 186 & 173 & 282 & 346 \\
\hline Inlet invert ele $(\mathrm{m})$ & 436.4 & 442.4 & 432.4 & 424.4 & 449.4 & 447.4 \\
\hline Inlet invert offset & 0.00 & " & $"$ & " & , & $”$ \\
\hline $\begin{array}{l}\text { Outlet invert } \\
\text { ele }(\mathrm{m})\end{array}$ & 435.4 & 441.4 & 424.4 & 421.4 & 447.4 & 445.4 \\
\hline Outlet invert offset & 0.00 & " & \# & " & " & , \\
\hline Remark & Qc ok & Qc Not ok & Qc ok & Qc ok & Qc ok & Qc ok \\
\hline
\end{tabular}

\begin{tabular}{|c|c|c|c|c|c|c|c|c|}
\hline $\mathrm{CH}$ & 7 & 8 & 9 & 10 & 11 & 12 & 13 & 14 \\
\hline $\begin{array}{l}\text { Catchment } \\
\mathrm{A}\left(\mathrm{m}^{2}\right)\end{array}$ & 9274 & 4921 & 92767 & 11667 & 10000 & 5294 & 24874 & 71974 \\
\hline $\begin{array}{l}\text { Ave runoff } \\
\text { coe }\end{array}$ & 0.5 & 0.5 & 0.65 & 0.5 & 0.65 & 0.5 & 0.5 & 0.65 \\
\hline Return period & $2 y r s$ & $2 \mathrm{yrs}$ & $2 y r s$ & $2 y r s$ & $2 y r s$ & $2 y r s$ & $2 y r s$ & $2 y r s$ \\
\hline $\mathrm{T}_{\mathrm{c}} \mathrm{K}$ (mins) & 5 & 5 & 7 & 12 & 4 & 7 & 6 & 8 \\
\hline Tc A(mins) & 14 & 9 & 7 & 18 & 4 & 13 & 16 & 8 \\
\hline I к $(\mathrm{mm} / \mathrm{hr})$ & 95 & 95 & 91 & 85 & 96 & 91 & 93 & 90 \\
\hline $\mathrm{I}_{\mathrm{A}}(\mathrm{mm} / \mathrm{hr})$ & 81 & 89 & 91 & 74 & 96 & 82 & 76 & 90 \\
\hline $\begin{array}{l}\text { Manning's } \\
\operatorname{coe}(n)\end{array}$ & 0.013 & $”$ & " & ", & $”$ & , & $”$ & ", \\
\hline $\begin{array}{l}\text { Drain size(b x } \\
\text { y) }\end{array}$ & $0.6 \times 0.6$ & " & " & ", & " & " & $”$ & ", \\
\hline Drain type & $”$ & , & , & , & $"$ & " & $”$ & $”$ \\
\hline Slope $\%$ & 0.755 & 1.377 & 3.19 & 0.92 & 5.67 & 0.99 & 0.664 & 2.953 \\
\hline $\operatorname{Vel}(\mathrm{m} / \mathrm{s})$ & 0.74 & 0.82 & 1.91 & 0.71 & 1.67 & 0.94 & 0.91 & 1.9 \\
\hline $\mathrm{Q}_{\mathrm{K}}\left(\mathrm{m}^{3} / \mathrm{s}\right.$ & 0.122 & 0.065 & 1.524 & 0.138 & 0.173 & 0.067 & 0.321 & 1.169 \\
\hline $\mathrm{QN}\left(\mathrm{m}^{3} / \mathrm{s}\right.$ & 0.103 & 0.061 & 1.524 & 0.120 & 0.173 & 0.061 & 0.263 & 1.169 \\
\hline $\mathrm{Q}_{c}\left(\mathrm{~m}^{3} / \mathrm{s}\right)$ & 0.361 & 0.295 & 0.688 & 0.256 & 0.601 & 0.338 & 0.328 & 0.684 \\
\hline Ch length (m) & 133 & 145 & 378 & 435 & 229 & 203 & 151 & 440 \\
\hline $\begin{array}{l}\text { Inlet invert } \\
\text { ele(m) }\end{array}$ & 445.4 & 446.4 & 421.4 & 438.4 & 434.4 & 437.4 & 435.4 & 434.4 \\
\hline $\begin{array}{l}\text { Inlet invert } \\
\text { offset }\end{array}$ & $"$ & $"$ & $"$ & $"$ & $"$ & $"$ & $"$ & $"$ \\
\hline $\begin{array}{l}\text { Outlet invert } \\
\text { ele(m) }\end{array}$ & 444.4 & 444.4 & 409.4 & 434.4 & 421.4 & 435.4 & 434.4 & 421.4 \\
\hline $\begin{array}{l}\text { Outlet invert } \\
\text { offset }\end{array}$ & $"$ & $"$ & $"$ & $"$ & $"$ & $"$ & $"$ & $"$ \\
\hline Remark & Qc ok & Qc ok & $\begin{array}{c}\text { Qc not } \\
\text { ok }\end{array}$ & Qc ok & Qc ok & Qc ok & Qc ok & Qc Not ok \\
\hline
\end{tabular}


Table 9: A Redesign of Inadequate Drainage Channels for Basin C

\begin{tabular}{|c|c|c|c|c|c|c|c|c|c|}
\hline $\mathrm{CH}$ & 1 & 2 & 4 & 5 & 6 & 7 & 8 & 9 & 10 \\
\hline $\operatorname{Area}\left(\mathrm{m}^{2}\right)$ & 17333 & 55079 & 11235 & 6116 & 18763 & 9274 & 4921 & 92767 & 11667 \\
\hline $\begin{array}{l}\text { Ave. runoff } \\
\text { coe }\end{array}$ & 0.5 & 0.5 & 0.65 & 0.5 & 0.5 & 0.5 & 0.5 & 0.65 & 0.5 \\
\hline Slope(\%) & 0.55 & 0.95 & 1.73 & 0.73 & 0.58 & 0.76 & 1.38 & 3.20 & 0.92 \\
\hline $\begin{array}{l}\text { Manning } \\
\text { coe } n\end{array}$ & 0.013 & 0.013 & 0.013 & 0.013 & 0.013 & 0.013 & 0.013 & 0.013 & 0.013 \\
\hline Drain size & $0.3 \times 0.6$ & $0.4 \times 0.8$ & $0.25 \times 0.6$ & $0.18 \times 0.36$ & $0.3 \times 0.6$ & $0.2 \times 0.4$ & $0.15 \times 0.3$ & $0.45 \times 0.90$ & $0.25 \times 0.5$ \\
\hline $\operatorname{Vel}(\mathrm{m} / \mathrm{s})$ & 1.21 & 1.04 & 1.54 & 1.15 & 1.23 & 1.53 & 1.40 & 1.91 & 1.10 \\
\hline $\mathrm{Q}\left(\mathrm{m}^{3} / \mathrm{s}\right)$ & 0.217 & 0.734 & 0.193 & 0.075 & 0.221 & 0.122 & 0.065 & 1.524 & 0.138 \\
\hline $\mathrm{Q}_{\mathrm{C}}\left(\mathrm{m}^{3} / \mathrm{s}\right)$ & 0.289 & 0.821 & 0.320 & 0.100 & 0.300 & 0.153 & 0.072 & 2.06 & 0.231 \\
\hline
\end{tabular}

\section{CONCLUSION}

Different methods may be employed in the design of drains, the method ranges from trial and error selection of the sizes and checking whether or not the velocity of flow and capacity are satisfied. The design is basically aimed at determination of the drain section and slope.

This research presents an analysis for the determination of the capacity and adequacy of drainage channels in University of Nigeria, Nsukka campus. Topographic map, meteorological data, geometric measurement of drainage channels and application of rational models, Kirpich's equation, new equation of time of concentration and manning's equation were used in the analysis to obtain the discharge and drain capacities of the channels.

Results obtained from the analysis showed that a relationship exist between the rainfall intensity and the time of concentration. As the time of concentration reduces, the rainfall intensity increases. All the drainage channels of basin A had velocities ranging from 1 to $2 \mathrm{~m} / \mathrm{s}$ and the drain capacities are okay. All the drainage channels of basin $\mathrm{B}$ had velocities ranging from 2 to $4 \mathrm{~m} / \mathrm{s}$ and the drain capacities are okay. Some drainage channel of basin C had drain capacities less than actual discharge and flow velocities less than $1 \mathrm{~m} / \mathrm{s}$. A redesign of inadequate drainage channels of basin $\mathrm{c}$ was made to ensure that the drains are adequate enough to safely discharge the runoff generated.

This study suggests that; proper design, computations (analysis), adequate construction and maintenance of drainage channels be made ensuring that the velocity satisfies the minimum requirement. In order to increase the velocity, the slope had to be increased. However, velocities excess of $6 \mathrm{~m} / \mathrm{s}$ should be avoided to prevent scouring on the drains.

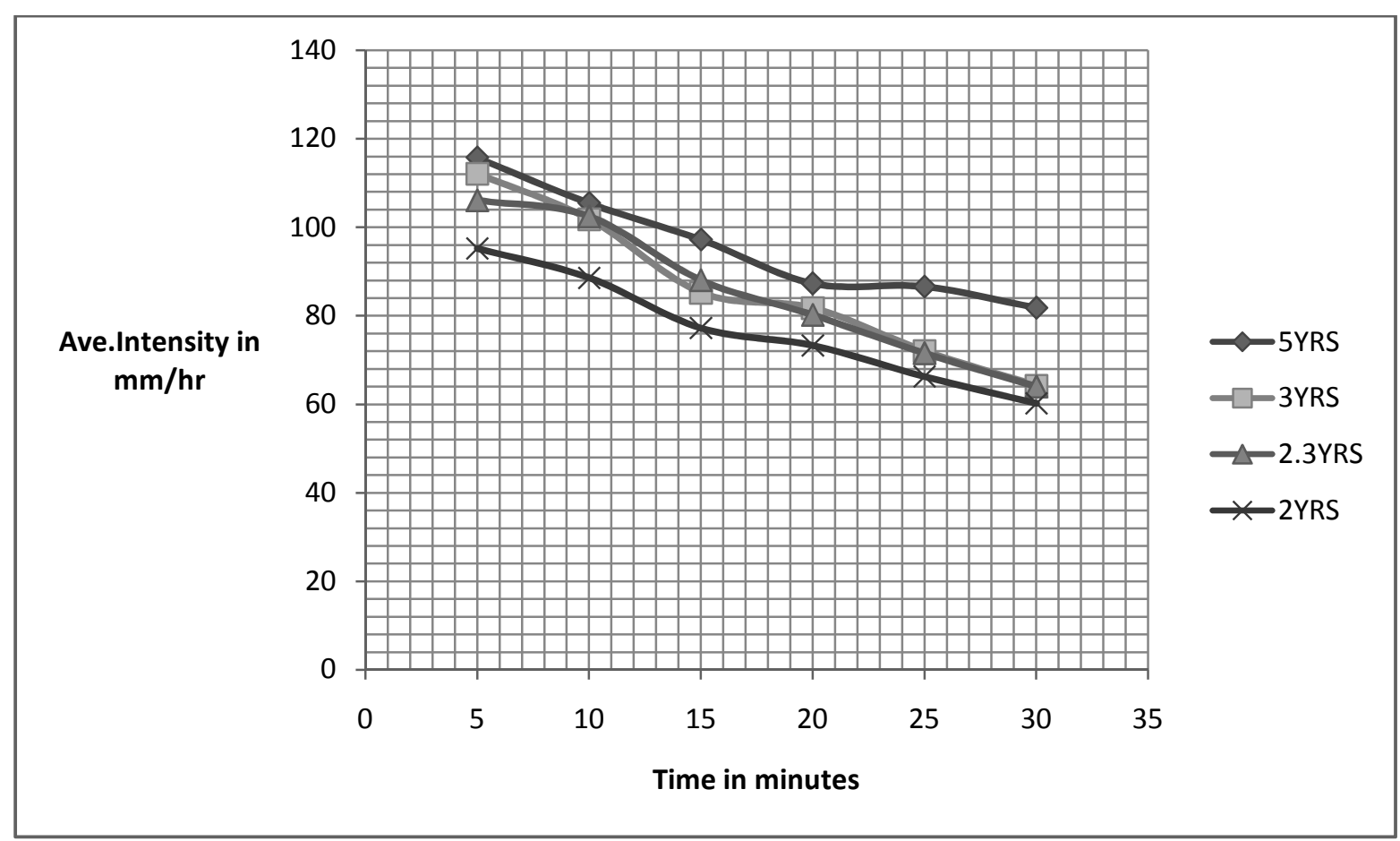

Figure 4: Rainfall frequency for 2-5yrs of UNN 


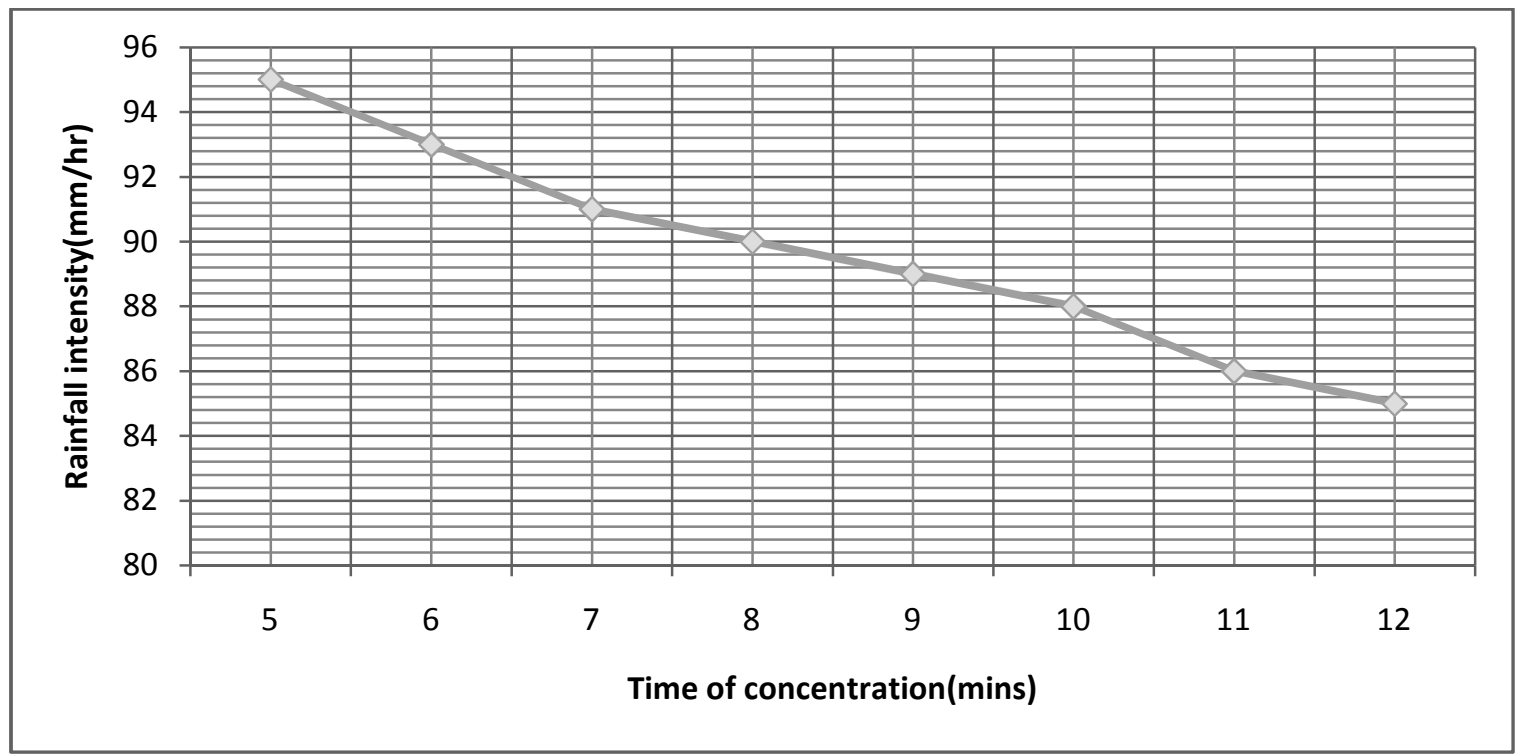

Figure 5: Variation ofrainfall intensity with time of concentration.

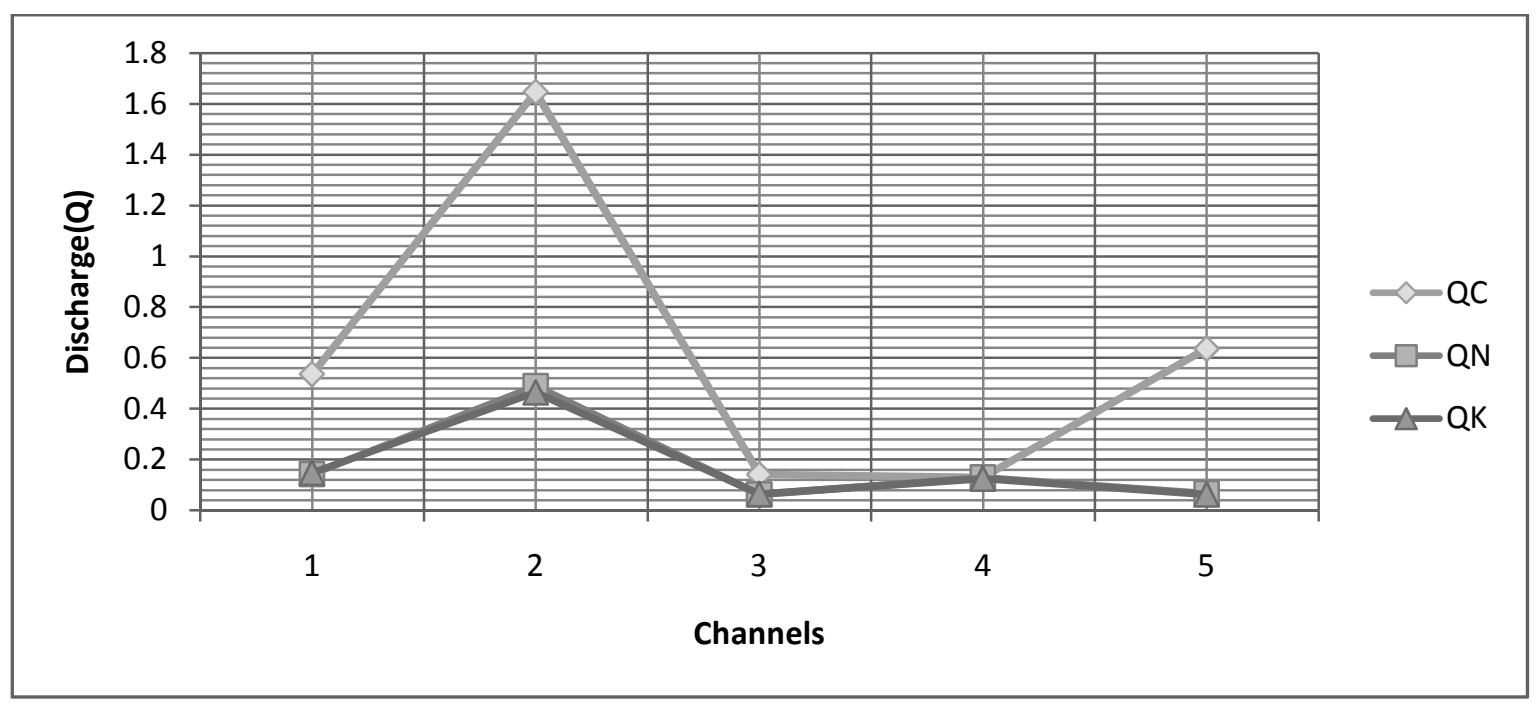

Figure 6: Comparison of discharge and drainage capacity from drainage channels of basin $A$

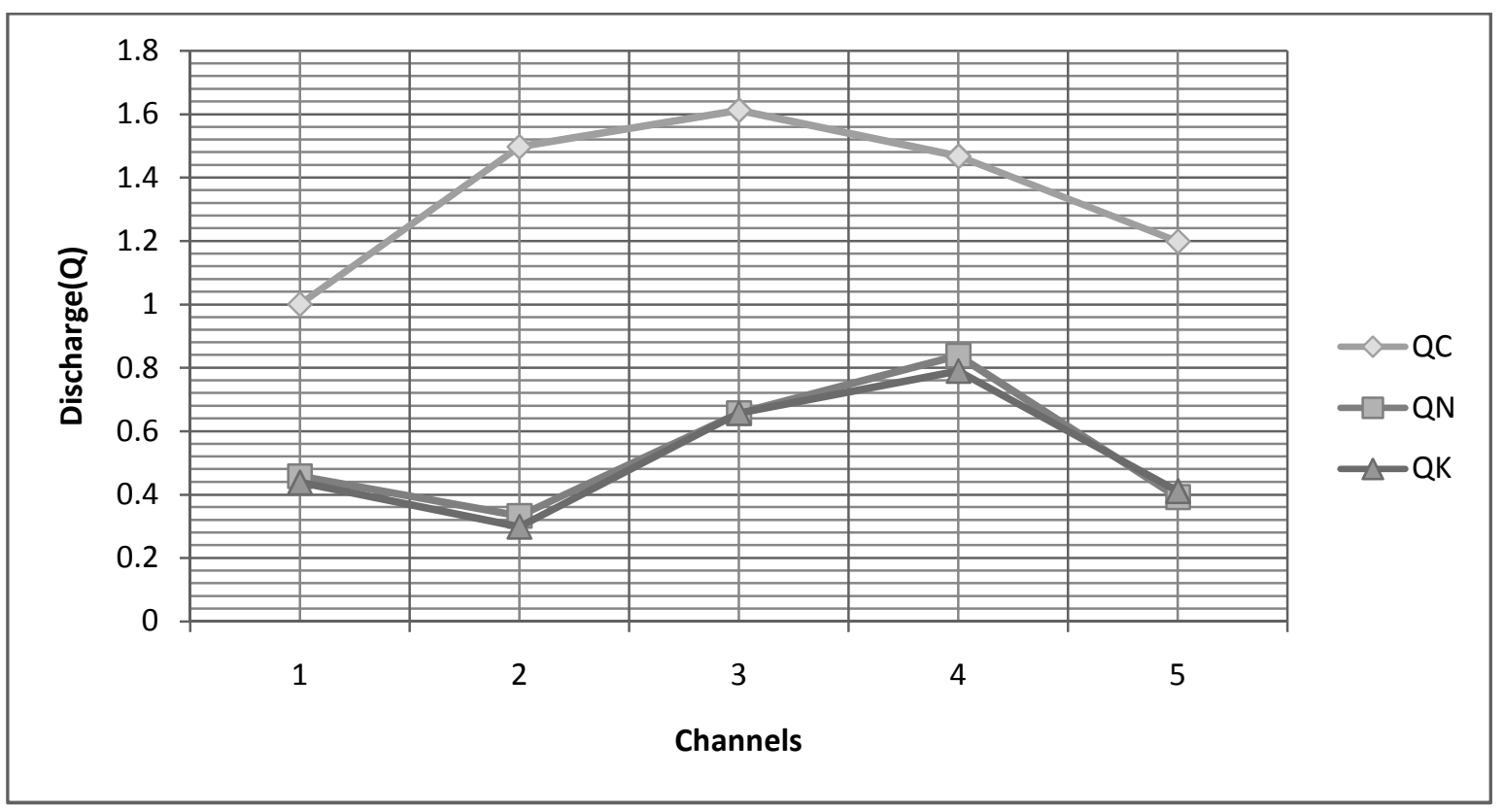

Figure 7: Comparison of discharge and drainage capacity from drainage channels of basin $B$ 


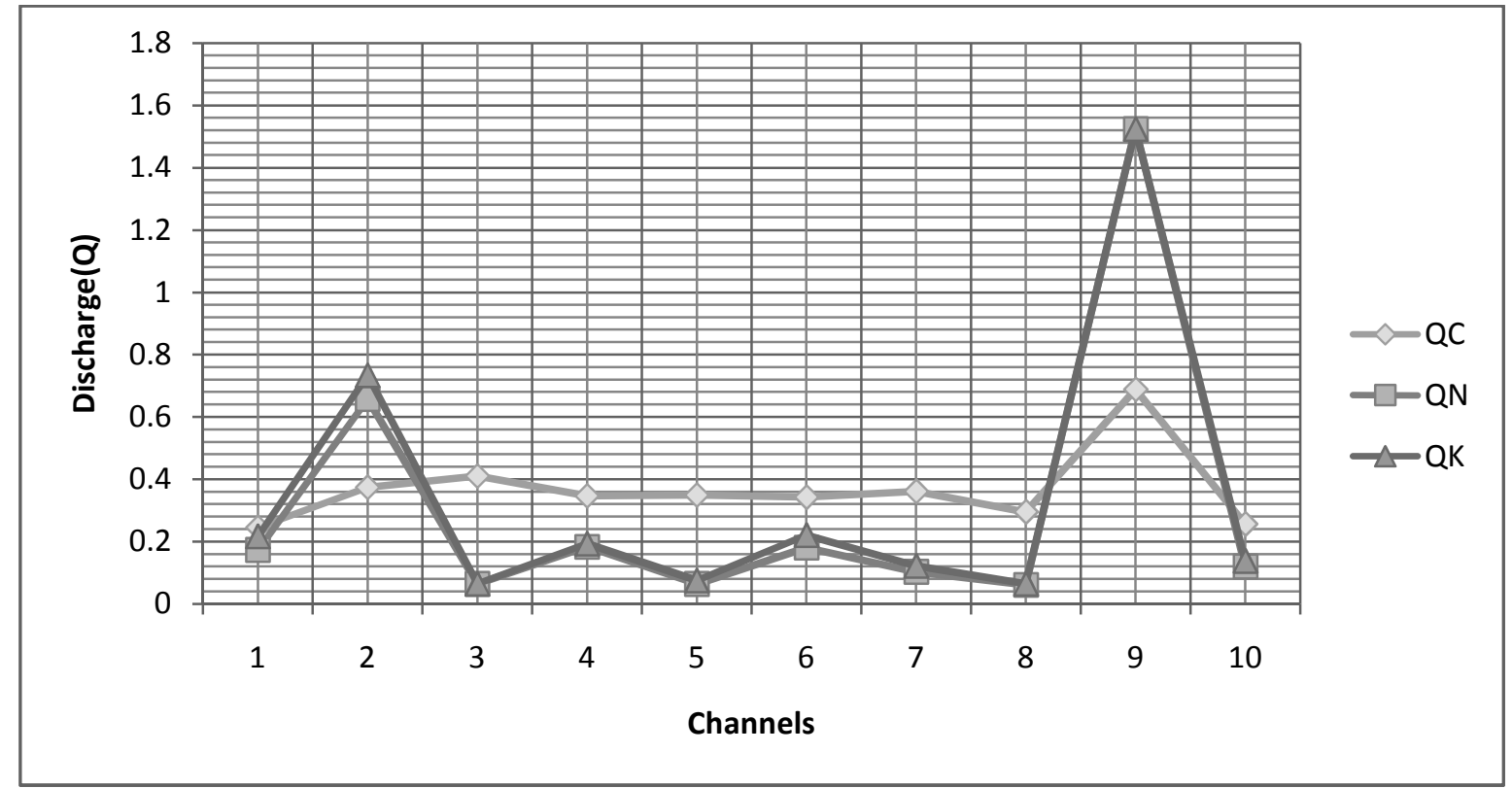

Figure 8: Comparison of discharge and drainage capacity from drainage channels of basin $C$

\section{REFERENCES}

[1] David, A.C. Water- Resources Engineering, Pearson Prentice Hall, New Jersey, 2006.

[2] Agunwamba, J. C. Waste Engineering and Management Tools, Immaculate Publication, Enugu, 2001.

[3] Andreas L, and Veneziano D, Intensity-DurationFrequency Curves from Scaling Representations of Rainfall. Department of Civil and Environmental Engineering, MIT, Cambridge, USA, 2006.

[4] Brian H, Zelinka C, Castello C, and Curtis D, Spatial Analysis of Storms Using GIS. Unpublished paper, One Rain Inc. 9267 Greenback Lane, Orangevale, 2006.
[5] Gerold, L. A. and Watkins D.W . "Short Duration Rainfall Frequency Analysis in Michigan Using Scale-Invariance Assumptions". Journal of Hydrologic Engineering, Volume 10, number 6, 2005, pp. 450-457

[6] Kirpich, P.Z. "Time of Concentration of Small Agricultural Watersheds". Journal of Civ.Eng. Vol. 10, No 6, 1940, pp 362.

[7] Prakash .A. Water Resources Engineering, ASCE Press, New York, 2004.

[8] Chow V.T, Maidment D.R, Mays LW, Applied hydrology, McGraw Hill, New York, 1988.

[9] American Society of Civil Engineers, Design and Construction of Urban Storm Water Management Systems, American Society of Civil Engineers, New York, 1992. 